Рекомендована д. фрармац. наук, профр. Р. Б. Лесиком

УДК 615.213:616.853:547.466.3

\title{
АНТИКОНВУЛЬСАНТИ, ЩО МАЮТЬ ГАМК-ЕРГІЧНИЙ МЕХАНІЗМ ДІї
}

\author{
СЛ. О. Перехода

\section{Національний фрармацевтичний університет, Харків}

\begin{abstract}
Резюме: наведено літературний огляд сучасних протисудомних засобів, що мають переважно ГАМК-ергічний механізм дії. Узагальнено перспективні напрямки хімічної модифрікації та наведено рекомендації щодо подальшого пошуку антиконвульсантів ГАМК-ергічної дії.
\end{abstract}

Ключові слова: епілепсія, механізм дії, ГАМК, протисудомний засіб.

Лікування епілепсії має важливе значення у зв'язку з високою поширеністю цього захворювання, його соціальною значущістю. Хворі на епілепсію потрапляють у дорожньо-транспортні пригоди або одержують побутові травми, через що близько 5 \% 3 них щорічно госпіталізовують. Кількість госпіталізованих хворих в Україні досягає близько 5 тис. пацієнтів на рік, середня вартість госпіталізації 1,2-1,4млн доларів на рік.

Проблемою цілеспрямованого пошуку нових протисудомних засобів займається велика кількість вчених, і хоча деколи зустрічаються публікації про виявлення протисудомних властивостей у лікарських рослин та субстанцій тваринного походження [1-4], більшість антиконвульсантів представлена синтетичними сполуками [5].

Протягом останніх десятиліть з'явилися нові лікарські засоби, які ефективно застосовуються при лікуванні епілепсії [6]. Але враховуючи те, що всі вони, на жаль, мають велику кількість побічних ефектів, і той фракт, що пацієнт зазвичай повинен приймати їх протягом всього життя, необхідно постійно вдосконалювати лікарську терапію шляхом розширення арсеналу протисудомних засобів [7-9]. В свою чергу, розширення арсеналу антиконвульсантів потребує детального вивчення механізмів дії та зв'язку «структура - антиконвульсивна активність» в рядах існуючих препаратів.

Дія протисудомних препаратів заснована на пригніченні збудливості нейронів епілептичного вогнища або на гальмуванні іррадіації патологічної імпульсації з епілептогенного вогнища на інші відділи мозку [10]. 3 метою пригнічення збудливості нейронів можуть бути використані деякі седативні, снодійні засоби та нейролептики. Однак у зв'язку з необхідністю тривалого (протягом багатьох місяців і навіть років) приймання і важливістю збереження психічної, фрізичної активності і працездатності хворих на епілепсію, седативний і снодійний ефекти, що ними викликаються, дуже небажані. Тому більш доцільне застосування спеціальних протиепілептичних препаратів, здатних вибірково знижувати судомну активність головного мозку без вираженого гальмування центральної нервової системи в цілому. Протиепілептичні засоби зменшують частоту і силу нападів, уповільнюють процес деградації психіки. Наявність великої кількості препаратів для лікування епілепсії пояснюється різноманіттям проявів цієї хвороби.

Механізм розвитку судомного нападу головним чином пов'язаний з порушенням обміну та фрункцій нейромедіаторних систем синаптичної передачі [11]. Тому знання нейромедіаторних механізмів дії протиепілептичних засобів важливо не тільки 3 теоретичної, але й практичної точки зору - для цілеспрямованого підбору протисудомних препаратів у кожному конкретному клінічному випадку. Серед відомих протиепілептичних засобів можна виділити препарати різних хімічних груп, які не мають між собою структурної подібності [12]. Аналіз дії протисудомних засобів доводить наявність трьох механізмів (ГАМК-ергічний, глутаматергічний, прямий вплив на проведення електричного імпульсу регуляцією іонних каналів нейронів), переважним 3 яких є ГАМК-ергічний [13]. Ефект ГАМК здійснюється через специфрічний рецептор, який може бути групою окремих, добре помітних підтипів рецепторів або набором множинних станів одного типу рецептора [15]. ГАМК ділянки зв'язування: для ГАМК - це ГАМК-зв'язуючий центр, що активує хлорні канали, і для бензодіазепінів - бензодіазепін-зв'язуючий чентр, що підсилює цей еорект. Роль ГАМК - рецепторів у генезі пароксизмальних станів на даний час загальновизнана, їх стан може модулюватися як чисельними позитивними (барбітурати, бензодіазепіни, нейростероїди), так і негативними (пікротоксин, бікукулін) алостеричними модуляторами [12].

Визнання ролі порушення ГАМК-ергічної системи в розвитку судомних нападів стало стимулом для розробки антиконвульсантів, що впливають на різні ланки ГАМК-ергічної синаптичної передачі.

Та обставина, що ГАМК дуже погано проникає крізь гематоенцефалічний бар'єр, ускладнює за-

ISSN 2312-0967. Фармацевтичний часопис. 2015. № 2 
стосування її в клініці, змушує звернутися до речовин, що близькі до неї за хімічною будовою і фрізіологічною дією, але краще проникають крізь ГЕБ. Один з напрямків пошуку антиконвульсантів, що активують ГАМК-ергічну передачу, реалізований створенням препаратів, структурно подібних ГАМК [14].

Молекула ГАМК $є$ гнучкою цвіттер-іонною молекулою, яка може існувати в різних конформаціях (рис.1). Оптимальна довжина її ланцюжка досягається при чотирьох атомах вуглецю 3 відстанню 5-6 ангстрем між зарядами - для максимальної інгібуючої дії і 3,7-4,5 ангстрем - для збуджувального ефректу [16]. Методами квантово-хімічних розрахунків, рентгеноструктурного аналізу, вивченням особливостей ефекту синтетичних аналогів з жорстко фріксованою будовою і ряду природних агоністів і антагоністів ГАМК було встановлено, що кращою для прояву гальмівного ефекту $€$ витягнута конорормація ГАМК (відстань між зарядженими атомами $\mathrm{N}^{+}$i О- складає в цьому випадку 5,4 \pm 0,4 А, для згорнутої конформації вона знаходиться в межах 4,2-4,7 $\AA$ ). В кристалах ГАМК знаходиться виключно у витягнутій конформації, а у розчинах її молекули існують в різних конформаціях [17]. Тому пошук перспективних антиконвульсантів доцільно проводити і серед аліфратичних сполук, що подібні витягнутій конфрормації ГАМК і серед похідних п'ятичленних гетероциклів, що мають схожість будови зі згорнутою конорормацією ГАМК.

Ідея використовувати ГАМК та її аналоги як лікарські речовини стала частиною ефективної стратегії пошуку ліків з будовою, подібною до ендогенних сполук. На наш погляд, такий підхід може гарантувати селективність дії та забезпечити низьку токсичність. Доведено, що введення різних радикалів $\left(R^{1}-R^{6}\right)$ в молекулу ГАМК призводить до значних змін активності одержаних похідних. Узагальнюючи попередні дослідження, ми дійшли висновку, що наявність атома хлору або гідроксильної групи при C-2 ГАМК $\left(\mathrm{R}^{6}\right.$ = C1, OH) надає цим похідним седативні та антиконвульсивні властивості. Введення в молекулу аміногрупи $\left(\mathrm{R}^{6}=\mathrm{NH}_{2}\right) €$ небажаним, тому що знижує ГАМКподібну активність [18]. Введення за положенням C-3 ГАМК гідроксильної групи $\left(\mathrm{R}^{5}=\mathrm{OH}\right)$ призводить до появи помірного протисудомного есректу, що стало приводом для створення препарату Гамібетал (Буксамін), який на даний час з успіхом застосовують у клініці епілепсії [18].<smiles>[R]C(C(=O)O)C([R5])C([R])[NH+]([R])[R]</smiles><smiles>NCC(O)CC(=O)O</smiles>

Гамібетал

На наш погляд, доцільною є спроба введення в молекулу ГАМК двох гідроксильних груп, що на даний момент не реалізовано.

У арилзаміщених похідних ГАМК $\left(\mathrm{R}^{5}=\mathrm{Ph}\right)$ - препаратів френігама (фенібут) і ліоресал (баклофен), також виявлено виражену транквілізуючу і помірну протисудомну дію. Діюча речовина препарату фенігама - 3-среніл ГАМК $є$ активною тільки в (S) - (+)-срормі [19].<smiles>NCC(CC(=O)O)c1ccccc1</smiles><smiles>NCC(CC(=O)O)c1ccc(Cl)cc1</smiles>

При подальшому пошуку антиконвульсантів подібних за будовою ГАМК слід враховувати хіральність молекули потенційного антиконвульсанта. Просторова орієнтація замісників в молекулі лікарської речовини щодо ГАМК-рецептора може відігравати вирішальну роль у наявності ефекту.

За даними літератури, естерифікація карбоксильної групи покращує гальмування моторної активності (ГАМК у вигляді естеру краще долає ГЕБ), але при цьому збільшується токсичність препарату. Метилювання аміногрупи $\left(\mathrm{R}^{1}\right.$ та $\left.\mathrm{R}^{2}=\mathrm{Me}\right)$ або введення ме-

Рис. 1. Моделі похідних молекули ГАМК: а) витягнута конформація; в) згорнута конформація.

ISSN 2312-0967. Pharmaceutical review. 2015. № 2 


\section{Reviews}

тильної групи по C-2 $\left(\mathrm{R}^{6}=\mathrm{Me}\right)$ збільшує ліпофрільність молекули, але зменшує ГАМК-ефект синаптичного блокування. Амідування ГАМК або введення в молекулу по C-2 френільного замісника $\left(\mathrm{R}^{6}=\mathrm{Ph}\right)$ також $\epsilon$ небажаними напрямками хімічної модифрікації [20]. У амідної форми ГАМК (у-бутиролактам) протисудомна активність зовсім зникає.

Іншим напрямком пошуку антиконвульсантів, що активують ГАМК-ергічну передачу, є створення препаратів - агоністів ГАМК-рецепторів. До агоністів ГАМК-рецепторів належить велика група препаратів - похідних барбітурової кислоти (фенобарбітал, бензобаміл, гексамідин, бензонал), бензодіазепінів (карбамазепін, діазепам, клоназепам), похідних бурштинової кислоти (етосуксимід), або близьких за будовою до ГАМК сполук (дифенілгідантоїн, пропіонова кислота) [20]. Ці препарати взаємодіють із ГАМК алостеричні зміни, що сприяють підвищенню чутливості до ГАМК, що в результаті протидіє розвитку деполяризації нейронів.

Однією 3 груп препаратів - агоністів ГАМКрецепторів $€$ похідні барбітурової кислоти (1-3, табл. 1) [21]. Цікаво, що барбітурова кислота не має ні гіпнотичної (снодійної), ні протисудомної дії. Вивчення залежності «структура-активність» у ряду барбітуратів дало можливість дійти певних висновків [22]:

1. Висока активність характерна для тих структур, які в положенні 5 мають френільний радикал. Введення другого френілу в молекулу веде до зниження активності.

2. Оптимальний рівень антиконвульсивної активності спостерігається в тих випадках, коли другий радикал при $\mathrm{C}^{5}$ - алкіл 3 кількістю атомів карбону 1-4. Введення вищих алкілів знижує антиконвульсивну активність.

3. N-метилювання френобарбіталу істотно не впливає на протисудомну активність (метилфенобарбітал).

4. N-метилювання у 5,5-діалкілбарбітуратів веде до підвищення антиконвульсивної активності та зниження рівня гіпнотичної активності (метабарбітал).

5. При введенні метоксиметильної групи в положення 1 або двох таких груп в положення 1 і 3 антиконвульсивна активність підвищується (етеробарб).

6. Антиконвульсивна активність барбітуратів підвищується, якщо обидва атома нітрогену заміщені ацетоксиметил-, бромометил-, бензоїльними групами.

Одним із препаратів, похідних барбітурової кислоти, який впродовж багатьох років і з успіхом застосовується як протиепілептичний засіб, є фенобарбітал

Таблиця 1. Похідні барбітурової кислоти

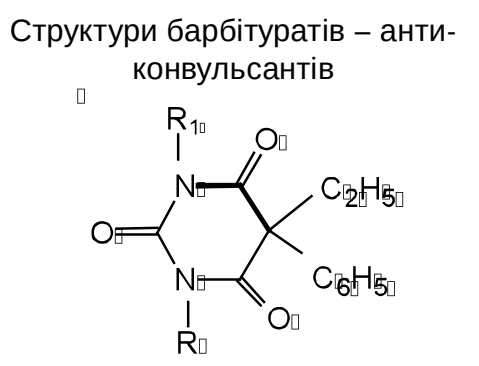<smiles>[R19]C1([R10])C(=O)N([2H])C(=O)N([2H])C1=O</smiles>

2.<smiles>[R]N1C(=O)NC(=O)C([Y10])(CC)C1=O</smiles>

$\mathrm{HBz}$

$$
\begin{aligned}
& \mathrm{R}_{1} \\
& \mathrm{H} \\
& \mathrm{H} \\
& \mathrm{H} \\
& \mathrm{CH}_{2} \mathrm{OH}
\end{aligned}
$$

$\mathrm{CH}_{2} \mathrm{OH}$

$\mathrm{Me}$

Et Et

$\mathrm{Ph}$

$\mathrm{R}_{1}=\mathrm{N}$-піперидил

$\mathrm{R}_{1}=$ н-гексил
Лікарські засоби

фенобарбітал

бензобарбітал

метилфенобарбітал

етеробарб

3.

ISSN 2312-0967. Фармацевтичний часопис. 2015. № 2 
(введений в клінічну практику Гауптманом в 1912 році) [23]. Він має високу протисудомну активність особливо при генералізованих тоніко-клонічних судомах і одночасно сильну седативну дію.

Фенобарбітал ефрективний при всіх видах епілепсії, за винятком типових абсансів. Останнім часом встановлено, що препарат надає подвійну дію - активує ГАМК -рецептори і блокує глутаматні рецептори [23]. Модисрікацією молекули френобарбіталу 3 метою збільшення ліпофрільності і пролонгування дії були створені бензобарбітал (4) і бензобаміл (5) препарати, що фрактично є проліками.<smiles>CCCC1(CC)C(=O)NC(=O)N(C(=O)c2ccccc2)C1=O</smiles>

4.<smiles>CCC1(CCC(C)C)C(=O)NC(=O)N(C(=O)c2ccccc2)C1=O</smiles>

5.

Бензобарбітал в процесі метаболізму утворює фенобарбітал, який і надає протисудомну дію. При цьому гіпноседативна дія у нього виражена менше, ніж у френобарбіталу [24].

Подальша хімічна модиорікація молекули френобарбіталу з метою зменшення снодійного ефекту привела до створення нового препарату - гексамідину (примідон, 6) [25].<smiles>CCC1(CC)C(=O)NCNC1=O</smiles>

6.

За хімічною будовою гексамідин є дезоксибарбітуратом і відрізняється від фенобарбіталу тим, що карбонільна група в положенні 2 заміщена на метиленову групу, у зв'язку з чим гексамідин не є уреїдом і не виявляє вираженого снодійного ефекту. Але одночасно за наявності в положенні 5 етильного і френільного радикалів, гексамідин, метаболізуючись в організмі шляхом окиснення до френобарбіталу, надає протисудом- ну дію [25]. Другий метаболіт гексамідину - френілетилмалонамід також $є$ активним протисудомним агентом. Період напіврозпаду примідону значно довший, ніж у оренобарбіталу, отже він має більш тривалу дію [25].

Електрофрізіологічні дослідження, проведені в 60-70-ті роки XX ст., показали, що ГАМК-ергічну передачу в ЦНС підсилюють також бензодіазепіни. Найбільш відомий 3 них діазепам - який $є$ агоністом ГАМК-хлоробензодіазепінового рецепторного комплексу. Цей препарат $€$ найбільш ефективним при купіюванні епілептичного статусу. Механізм дії бензодіазепінів пов'язаний зі специфічними бензодіазепіновими рецепторами (вони є агоністами цих рецепторів), що входять до складу постсинаптичного ГАМК $_{A}$-рецепторного комплексу [25]. Бензодіазепінові і ГАМК від одного, тому основний механізм дії бензодіазепінів - вплив на ГАМК-трансмісію (посилення ГАМКергічного гальмування в центральній нервовій системі) - аналогічний до механізму дії барбітуратів. Певну роль в реалізації ефектів бензодіазепінів можуть відігравати й інші медіаторні системи мозку. ГАМК вивільняється 3 нервових закінчень і зв'язується 3 $\Gamma_{\text {ГАМК }}$-рецепторами, активація яких збільшує проникність мембран нейронів для іонів $\mathrm{Cl}^{-}$. Комплекс ГАМК чу бензодіазепінову рецепторну ділянку, стимуляція якої бензодіазепінами викликає конформаційні зміни в ГАМК-рецепторах. Це підвищує афрінітет ГАМК до рецепторів і посилює її вплив на проникність мембран нейронів для іонів $\mathrm{Cl}$. При відсутності ГАМК ні бензодіазепіни, ні барбітурати в малих дозах не впливають на проникність мембран для іонів $\mathrm{Cl}^{-}$.

Порівняно з барбітуратами бензодіазепіни менше пригнічують ЦНС. Передозування бензодіазепінів до серйозних наслідків, зазвичай, не призводить, тоді як передозування барбітуратів (навіть відносно невелике) може призвести до летального результату [26]. До того ж, френобарбітал, поряд 3 іншими барбітуратами, за рахунок великої кількості побічних ефектів виключений зі списку обов'язкових лікарських засобів ВОО3 і заборонений для застосування в ряді країн. Популярність застосування бензодіазепінів пов'язана з їх відносно низькою токсичністю, проте на сьогодні встановлено, що тривале використання препаратів цієї групи може привести до розвитку толерантності, а також викликати когнітивні розлади та лікарську залежність [27]. Деякі бензодіазепіни метаболізуються в печінці до активних метаболітів, які мають більшу тривалість дії, ніж самі ліки. Так, наприклад, діазепам (Т1/2=20-80 годин) перетворюється в активний $\mathrm{N}$-дезметилдіазепам, період напівелімінації якого становить близько 200 годин [27].

Бензодіазепіни пригнічують ЦНС, але на відміну від інших анксіолітичних і снодійних засобів вони селективно підвищують функцію підтипів ГАМК рецепторів; їх застосування не викликає вираженого

ISSN 2312-0967. Pharmaceutical review. 2015. № 2 


\section{Reviews}

пригнічення дихання і загибелі пацієнтів. Саме тому внутрішньовенне введення бензодіазепінів (наприклад, діазепаму, клоназепаму, мідазоламу, лоразепаму) використовують при епілептичному статусі [28]. Подальший пошук антиконвульсантів, що активують ГАМК-ергічну передачу, сприяв до створенню в 1990 році препарату Топірамат (Топамакс, 7), який за хімічною будовою належить до класу сульсраматзаміщених моносахаридів (похідне фрруктопіранози) та суттєво відрізняється від існуючих антиконвульсантів [29].

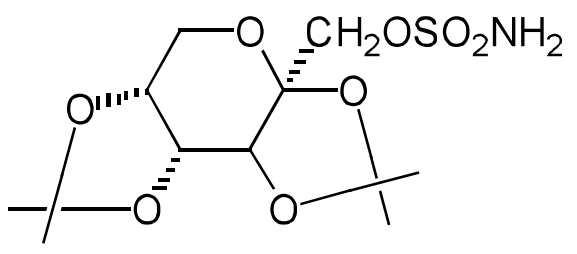

7.

\section{Література}

1. Yamazaki Y. Structure and function of snake venom cysteine-rich secretory proteins / Y. Yamazaki, T. Morita // Toxicon. - 2004. - Vol. 44. - P. 227-231.

2. Junqueira-de-Azevedo I. L. Lachesis muta (Viperidae) cDNAs reveal diverging pit viper molecules and scaffolds typical of cobra (Elapidae) venoms: implications for snake toxin repertoire evolution / I. L. Junqueira-de-Azevedo, A. T. Ching, E. Carvalho // Genetics. - 2006. - Vol. 173. P. 877-889.

3. Tsetlin V. I. Snake and snail toxins acting on nicotinic acetylcholine receptors: fundamental aspects and medical applicationsm / V. I. Tsetlin, F. Hucho // FEBS Lett. - 2004. - Vol. 557. - P. 9-13.

4. Wang J. Blocking effect and crystal structure of natrin toxin, a cysteine-rich secretory protein from Naja atra venom that targets the BKCa channel / J. Wang, B. Shen, M. Guo // Biochemistry. - 2005. - Vol. 44. - P. 10145-10152.

5. Броун Т. Эпилепсия. Клиническое руководство / Т. Броун, Г. Холмс; пер. с англ. - М. : Изд-во «БИНОМ», 2006. - С. 13.

6. Добрянська М. Фармакотерапія епілепсії: традиційні засоби та нові можливості / М. Добрянська // Нейро News. - 2008. - № 3. - C. 30.

7. Пылаева О. А. Побочные эффректы и осложнения антиэпилептической терапии / О. А. Пылаева, К. В. Воронкова, А. С. Петрухин // Фарматека. - 2004. №9/10. - C. 34-41.

8. Onat F. Adverse effects of new antiepileptic drugs / F. Onat, C. Ozkara // Drugs of Today. -2004. - Vol. 40, № 4. - P. 325-342.

9. Эпилепсия у взрослых (диагностика и лечение) / А. Е. Дубенко, Т. А. Литовченко, Л. А. Дзяк [и др.] // Новости мед. фрарм. - 2007. - № 215. - С. 14-15.

10. Гехт А. Б. Эпидемиология и фармакоэкономические аспекты эпилепсии / А. Б. Гехт // Журн. неврол. и психиат. - 2005. - Т. 105, № 8. - С. 63-68.

11. Харкевич Д. А. Фармакология / Д. А. Харкевич. 10-е изд. - М., 2009. - С. 457
Цей препарат потенціює активність ГАМК щодо ГАМК $_{\mathrm{A}}$-рецепторів, модулює активність самих ГАМК рецепторів, а також перешкоджає активації каїнатом чутливості каїнат / АМПК-рецепторів до глутамату. Крім того, топірамат подібно ацетазоламіду інгібує карбоангидразу, що є доцільним в терапії епілепсії [30]. Топірамат рекомендований для лікування пацієнтів із вперше діагностованою епілепсією, але, враховуючи, що основний метаболіт топірамату погано розчинне $\mathrm{N}$-ацетилпохідне, утворює камені в нирках, використання його в терапії епілепсії досить обмежене.

Проаналізовано зв'язок «структура-активність» у ряду сучасних антиконвульсантів, що мають переважно ГАМК-ергічний механізм дії.

Узагальнено перспективні напрямки хімічної модифрікації та наведено рекомендації щодо подальшого пошуку антиконвульсантів ГАМК-ергічної дії.

12. Abraham D.J. (ed.) Burger's Medicinal Chemistry and Drug Discovery, v. 2 - Drug Discovery and Drug Development Sixth Edition. - A Wiley-Interscience Puplication, A John Wiley and Sons, Inc.- 2003. - 817 p.

13. Ashutosh Kar. Medical Chemistry.- U.K.:«Anshan LTD» . - 2006. - $804 \mathrm{p}$.

14. Role of GABAergic inhibition in the coding of interaural time differences of low-frequency sounds in the inferior colliculus / W. R. D'Angelo, S. J. Sterbing, E.-M. Ostapoff, S. Kuwada // J. Neurophysiol. - 2005. - Vol. 93. - P. 3390-3400.

15. Harrison N. J. Molecular modeling of the GABA(C) receptor ligand-binding domain / N. J. Harrison, S. C. Lummis // J. Mol. Model. - 2006. - Vol. 12. - P. 317-324.

16. Campagna-Slater V. Molecular modelling of the GABAa ion channel protein / V. Campagna-Slater, D. F. Weaver // J. Mol. Graph. Model. - 2007. - Vol. 25. - P. 721-730.

17. Чупахин В. И. Моделирование закрытой и открытой формы ГАМК _-рецептора: анализ лиганд-рецепторных взаимодействий для ГАМК-связывающего центра / В. И. Чупахин, В. А. Палюлин, Н. С. Зефиров // Доклады Академии Наук. - 2006. - Т. 408, № 5. - С. 693-698.

18. Bazil C. W. Effects of antiepileptic drugs on sleep structure: are all drugs equal / C. W. Bazil // CNS Drugs. 2003. - Vol. 17. - P. 719-728.

19. Zorumsky C. F. Insights into the structure and functions of GABA - benzodiazepine receptors: ion channels and psychiatry / C. F. Zorumsky, K. E. Isenberg // J. Psychiatry. - 1991. - P. 148-162.

20. Гехт А. Б. Эпидемиология и фрармакоэкономические аспекты эпилепсии / А.Б.Гехт // Эпилепсия медикосоциальные аспекты, диагностика и лечение: сб. научн. тр. - М., 2004. - С. 129-134.

21. Калинин В. В. Противосудорожные и психотропные свойства антиэпилептических препаратов при лечении больных эпилепсией / В. В. Калинин, Е. В. Железнова. М. : Артинфро паблишинг, 2008. - С. 245

22. Зефиров // Доклады Академии Наук. - 2006. T. 408, № 5. - С. 693-698.

ISSN 2312-0967. Фармацевтичний часопис. 2015. № 2 
23. Thomas L. Lemke, David A. Williams O. Foye's principles of medicinal chemistry / Thomas L. Lemke. 6-th. - Baltimor: the Point, 2008. - 1348 p.

24. Палмер Р. Д. Противоэпилептические средства / Р. Д. Палмер, Б. С. Мелдрум ; под ред. Б. Катцунга // Базисная и клиническая фрармакология. - М. : Бином, 2007. - C. 464-491.

25. Бертрам Г. К. Базисная и клиническая фрармакология / Г. К. Бертрам. - 2-е изд. - М., 2007. - С. 547

26. Рациональная антиэпилептическая фрармакология: рук. для врачей / К. В. Воронкова, А. С. Петрухин, О. А. Пылаева, А. С. Холин. - М. : Бином пресс, 2008. $192 \mathrm{c}$.

27. Tomson T. Therapeutic monitoring of antiepileptic drugs for epilepsy / T. Tomson, M. Dahl, E. Kimland // Cochrane Database Syst Rev. - 2007. - Vol. 1. - P. 216.

28. Дубенко А.Е.Применениебрендовыхигенерических противоэпилептических препаратов / А. Е. Дубенко // Нейро NEWS. -2008. - № 3. - С. 13-18.

29. Topiramate pharmacokinetics in children and adults with epilepsy: a case-matched comparison based on therapeutic drug monitoring data / D. Battino, D. Croci, A. Rossini [et al.] // Clin. Pharmacokinet. - 2005. - Vol. 44. - P. 407-416.

30. Topiramate, carbamazepine and valproate monotherapy: double-blind comparison in newly diagnosed epilepsy / M. D. Privitera, M. J. Brodie, R. H. Mattson [et al.] I/ Acta. Neurol. Scand. - 2003. - Vol. 107. - P. 165-175.

\title{
АНТИКОНВУЛЬСАНТЫ, ИМЕЮЩИЕ ГАМК-ЭРГИЧЕСКИЙ МЕХАНИЗМ ДЕЙСТВИЯ
}

\section{л. А. Перехода}

\author{
Национальный фрармацевтический университет, Харьков
}

Резюме: приведен литературный обзор современных противосудорожных средств, имеющих преимущественно ГАМК-эргический механизм действия. Обобщены перспективные направления химической модисикации и приведены рекомендации, которые могут быть использованы в дальнейшем поиске антиконвульсантов ГАМКэргического действия.

Ключевые слова: эпилепсия, механизм действия, ГАМК, противосудорожное средство.

\section{ANTICONVULSANTS WITH GABA-ERGIC MECHANISM OF ACTION}

\section{O. Perekhoda}

\section{National University of Pharmacy, Kharkiv}

Summary: a literary review of modern anticonvulsants that are predominantly GABA-ergic mechanism of action was given. Perspective directions of chemical modification and recommendations will later choose the most promising ways of modification to improve the efficiency search for new anticonvulsants that are predominantly GABA-ergic mechanism of action were summarized.

Key words: epilepsy, mechanism of action, GABA, anticonvulsant agent. 